\title{
Prevention of chronic graft-versus-host disease by stimulation with glucocorticoid-induced TNF receptor
}

\author{
Juyang Kim ${ }^{1}$, Woon Sun Choi ${ }^{1}$, \\ Hye Jeong $\mathrm{Kim}^{1}$ and Byungsuk Kwon ${ }^{1,2}$ \\ ${ }^{1}$ The Immunomodulation Research Center and \\ Department of Biological Science \\ University of Ulsan \\ Ulsan 680-749, Korea \\ ${ }^{2}$ Corresponding author: Tel, 82-52-259-2860; \\ Fax, 82-52-259-2740; E-mail, bkwon@mail.ulsan.ac.kr
}

Accepted 1 February 2006

Abbreviations: AICD, activation-induced cell death; $\mathrm{BDF}_{1},(\mathrm{C} 57 \mathrm{BL} / 6$ $\times D B A / 2) F_{1}$; cGVHD, chronic graft-versus-host disease; GITR, glucocorticoid-induced TNF receptor

\begin{abstract}
GITR (glucocorticoid-induced TNF receptor) is a recently identified member of the TNF receptor superfamily. The receptor is preferentially expressed on $\mathrm{CD} 4^{+} \mathrm{CD} 25^{+}$regulatory T cells and GITR signals break the suppressive activity of the subset. In this study, we wanted to reveal the in vivo function of GITR in chronic graft-versus-host disease (cGVHD), a lupus-like autoimmune disease. A single injection of anti-GITR monoclonal antibody (DTA-1) was effective in blocking the progression of CGVHD in the parent-into- $F_{1}$ model. Treatment of DTA-1 significantly decreased levels of $\operatorname{lgG}_{1}$ anti-DNA autoantibody, inhibited glomerulonephritis, and increased survival. The DTA-1-mediated inhibition of autoantibody production correlated with deletion of $B$ cells and could occur independently of $C D 4^{+} \mathrm{CD25}{ }^{+}$ regulatory $T$ cells. Our results indicate that anti-GITR monoclonal antibody may be used as a potential immunotherapeutic agent for preventing cGVHD.
\end{abstract}

Keywords: autoantibodies; B-lymphocytes; glomerulonephritis; graft vs host disease; immunotherapy; TNFRSF18 protein, mouse

\section{Introduction}

Graft-versus-host disease (GVHD) commonly occurs in patients who receive allogeneic stem cell trans- plants and remains a significant cause of morbidity (Murphy, 2000). In GVHD, immunocompetent donor cells attack a genetically disparate host. GVHD can exist as two distinct clinical entities: acute GVHD (aGVHD) and chronic GVHD (cGVHD). Donor CD8 ${ }^{+}$ $T$ cells and $T$ helper type 1 (Th1) $C D 4^{+} T$ cells cause acute GVHD by attacking host tissues (Murphy and Blazar, 1999), whereas donor Th2 $\mathrm{CD}^{+} \mathrm{T}$ cells play a key role in causing CGVHD by hyper-activating recipient $B$ cells and thus breaking $B$-cell tolerance to self-antigens (Gleichmann et al., 1984; Via and Shearer, 1988).

Numerous model systems have been developed for examining GVHD. In a well-known cGVHD model, cGVHD is induced by transferring parental $\mathrm{DBA} / 2 \mathrm{~T}$ cells into normal $(\mathrm{C} 57 \mathrm{BL} / 6 \times \mathrm{DBA} / 2) \mathrm{F}_{1}$ $\left(\mathrm{BDF}_{1}\right)$ mice. An immune complex glomerulonephritis that progresses to global glomerulosclersosis and renal failure is prominent in recipient $F_{1}$ mice (Bergijk et al., 1992), among other multisystem disorders comprising a spectrum of abnormalities such as vasculitis, polyarthritis, and mononuclear cell infiltration of multiple organs (Van Rappard-Van Der Veen et al., 1983; Rolink et al., 1983).

GITR (glucocorticoid-induced TNF receptor) was originally identified by comparing untreated and dexamethasone-treated murine T-cell hybridoma cells (Nocentini et al., 1999). Later, human GITR and its ligand were identified by searching an expressed sequence tag (EST) database (Kwon et al., 1999; 2003; Gurney et al., 1999). GITR expression is up-regulated on $\mathrm{T}$ cells after activation, and a high level of GITR is constitutively expressed on $\mathrm{CD} 4^{+} \mathrm{CD} 25^{+}$regulatory T cells (McHugh et al., 2002; Shimizu et al., 2002). GITR signals abrogate their suppressive function (McHugh et al., 2002; Shimizu et al., 2002). However, recent studies have demonstrated that GITR functions as a co-stimulatory molecule for conventional $\mathrm{T}$ cells in vitro (Ronchetti et al., 2004; Kohm et al., 2004; Ji et al., 2004; Kanamaru et al., 2004) and that GITRdeficient mouse $\mathrm{CD} 4^{+} \mathrm{CD} 25^{+}$regulatory $\mathrm{T}$ cells were able to exert the suppressive activity on conventional $\mathrm{CD} 25^{-} \mathrm{CD} 4^{+} \mathrm{T}$ cells as equally as wild-type $\mathrm{CD} 4^{+} \mathrm{CD} 25^{+}$regulatory $\mathrm{T}$ cells (Ronchetti et al., 2004).

The function of GITR remains largely to be defined. In this study, we wanted to reveal the in vivo function of GITR in the parental-into- $F_{1}$ cGVHD model. 


\section{Materials and Methods}

\section{Disease induction}

Female DBA/2 $\left(\mathrm{H}-2^{\mathrm{d}}\right)$ and $\mathrm{BDF}_{1}\left(\mathrm{H}-2^{\mathrm{b} / \mathrm{d}}\right)$ mice, 6-8 weeks of age, were purchased from Orient (Seoul, Korea) and were used to induce cGVHD. Single-cell suspensions in PBS were prepared from the spleens and lymph nodes of normal DBA/2 parental donors, filtered through a sterile mesh (BD Falcon, San Diego, CA) and washed. After the erythrocytes were lysed in hemolysis buffer $\left(144 \mathrm{mM} \mathrm{NH}_{4} \mathrm{Cl}\right.$ and 17 $\mathrm{mM}$ Tris- $\mathrm{HCl}, \mathrm{pH} 7.2$ ), the remaining cells were resuspended at $8 \times 10^{7}$ cells $/ 0.2 \mathrm{ml}$ in PBS. cGVHD was induced by transfer of $8 \times 10^{7}$ of DBA/2 parental cells into the tail vein of normal, unirradiated $\mathrm{BDF}_{1}$ mice. Immediately thereafter, $200 \mu \mathrm{g}$ of DTA-1 or control immunoglobulin (Ig) was administered intraperitoneally. In some experiments, CD $4^{+} \mathrm{CD} 25^{+}$ regulatory $T$ cells were removed by anti-CD25-conjugated magnetic beads (Miltenyi Biotech, Aurburn, CA) from DBA/2 spleen/lymph node cells. The remaining cells $\left(8 \times 10^{7}\right)$ were transferred into $\mathrm{BDF}_{1}$ mice to induce cGVHD.

\section{ELISA, flow cytometry, and histology}

ELISA was used to measure serum titers of antiDNA $\lg _{1}$ as described previously (Kim et al., 2005). Flow cytometry was also described previously (Kim et al., 2005). For histopathology, kidneys were collected and immediately immersed in $10 \%$ neutralbuffered formalin. The formalin-fixed tissue was em- bedded in paraffin, and $4-\mu \mathrm{m}$ sections were stained with hematoxylin and eosin (H\&E) or periodic acid schiff (PAS) and evaluated by microscopy. For immunohistochemistry, kidneys were embedded in optimal cutting temperature (OCT) compound (Sakura Fineteck, Torrence, CA) and snap-frozen in liquid nitrogen. Sections $(8 \mu \mathrm{m})$ were air-dried, fixed with acetone, and stained with fluorescein isothiocyanate (FITC)-conjugated anti- mouse IgG (BD Biosciences Pharmingen, San Diego, CA). Fluorescence was examined by confocal microscopy (Olympus, Tokyo, Japan).

\section{Statistical analysis}

Student's $t$-test was used to determine the statistical significance of differences between experimental groups.

\section{Results}

Agonistic anti-GITR antibody (DTA-1) has been shown to abolish the immunosuppressive activity of $\mathrm{CD} 4^{+} \mathrm{CD} 25^{+}$regulatory $\mathrm{T}$ cells (Shimizu et al., 2002). Since $\mathrm{CD} 4^{+} \mathrm{CD} 25^{+}$regulatory $\mathrm{T}$ cells can inhibit both humoral and cell-mediated branches of the immune response (Wood and Sakaguchi et al., 2003), we expected that DTA-1 would exacerbate cGVHD. Unexpectedly, a one-time administration of DTA-1 $(200 \mu \mathrm{g})$ at the phase of disease induction significantly blocked the production of autoantibody. As seen previously (Kim et al., 2005), high levels of
A

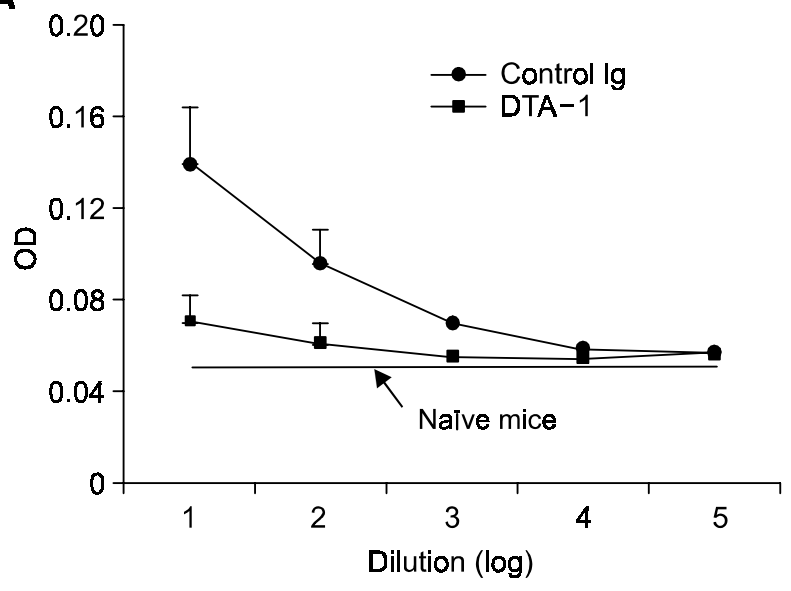

B

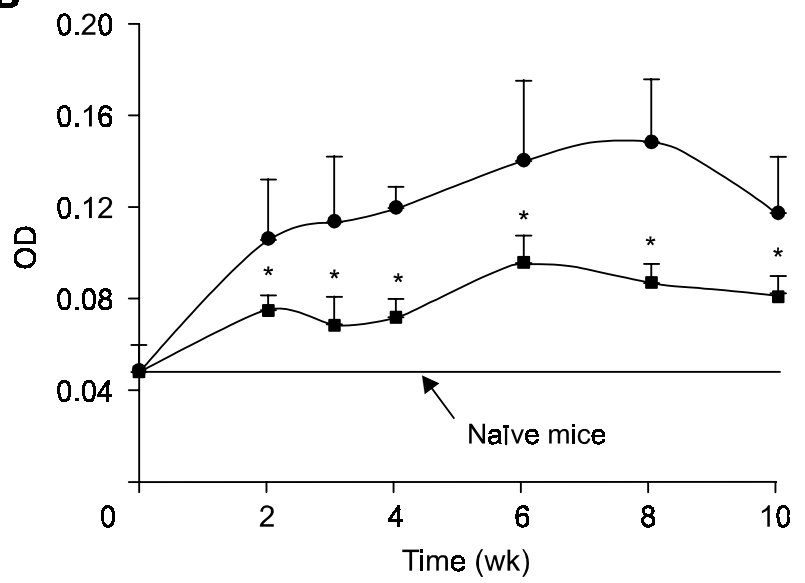

Figure 1. DTA-1 inhibits the production of $\operatorname{lgG}_{1}$ anti-DNA autoantibody in cGVHD. cGVHD was induced by transferring $8 \times 10^{7} \mathrm{DBA} / 2 \mathrm{spleen} /$ lymph node cells into BDF 1 mice. Immediately thereafter, $200 \mu \mathrm{g}$ of DTA-1 or control Ig was injected. Serum samples were collected every 1 or 2 weeks, and assayed in duplicate by ELISA for $\lg \mathrm{G}_{1}$ anti-DNA autoantibody. The optical density (OD) of duplicate samples for each mouse was measured at $450 \mathrm{~nm}$, using serially diluted serum samples. Titration curves for anti-DNA $\operatorname{lgG}_{1}$ are shown in the panel $A$ at week 2 . Similar titration curves were obtained at other time points. OD values are means $\pm S D$ ( $n=10$ per group) of 10 -fold dilution of samples and are representative of more than 3 independent experiments. ${ }^{*} P<0.05$, between the 2 groups at the indicated time points. 
A
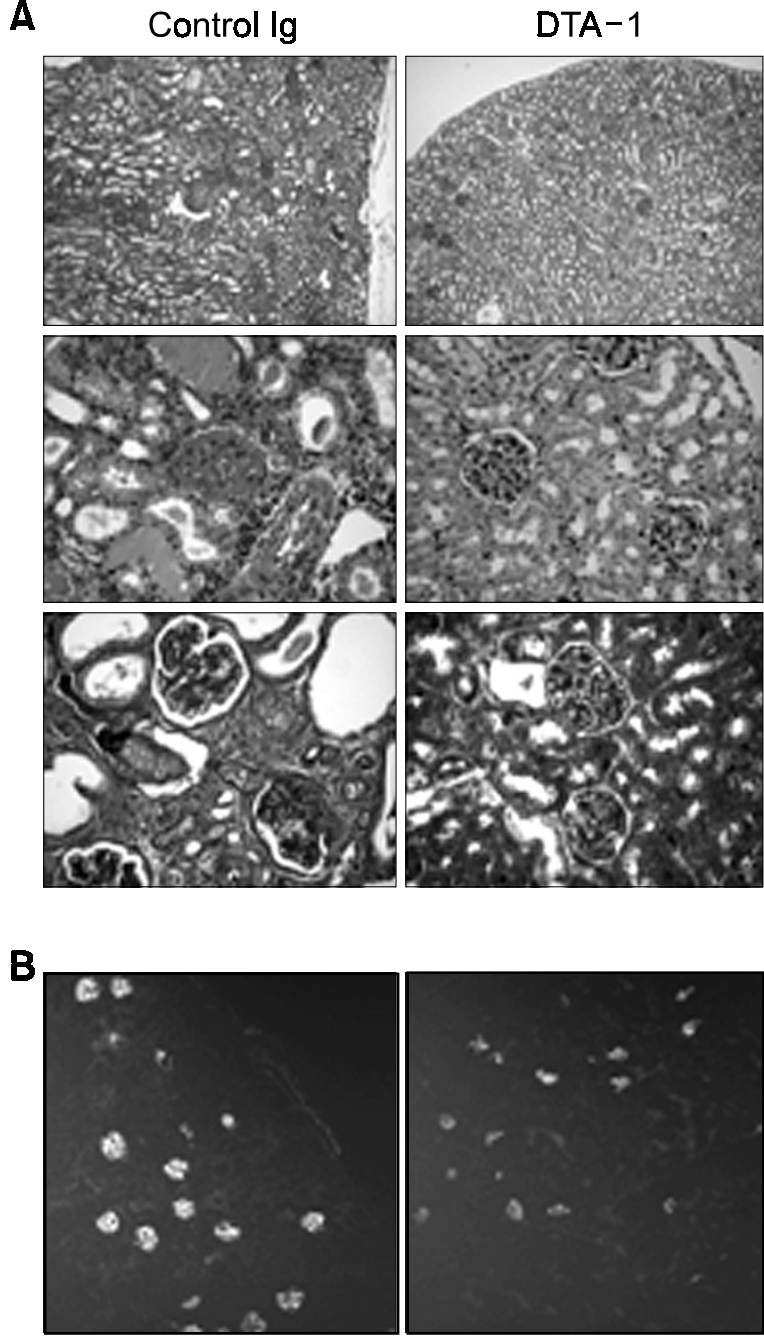

anti-DNA $\lg G_{1}$ began to be detected in the serum of control CGVHD mice at week 2 after disease induction (Figure 1). In contrast, administration of DTA-1 resulted in a marked reduction in levels of anti-DNA $\lg G_{1}$. The decrease was observed as early as week 2 and maintained thereafter (Figure 1).

Kidney disease is considered to be the primary cause of mortality in mice afflicted with cGVHD. In particular, autoantibody-immune complex deposits directly result in glomerular damage. As DTA-1 significantly inhibited autoantibody production, we investigated whether it could prevent renal disease. The kidneys from control cGVHD mice demonstrated severe glomerulonephritis. Virtually all of the glomeruli exhibited global or segmental glomerulosclerosis (Figure 2A). Histological sections from control cGVHD mice also displayed severe tubular damage, prominent perivascular inflammatory cell infiltrates and fibrosis (Figure 2A). In contrast, the general kidney pathology was greatly reduced in the

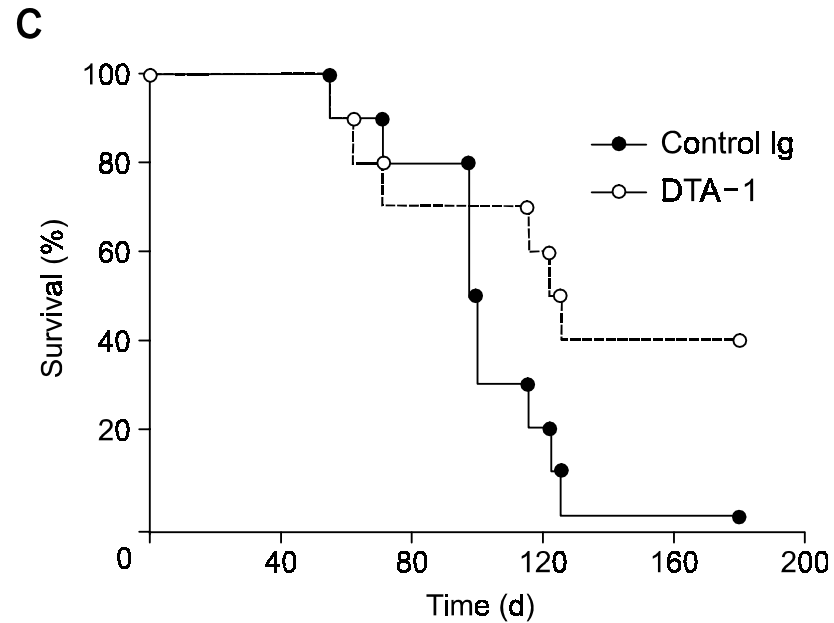

Figure 2. DTA-1 inhibits immune complex formation and glomerulonephritis. (A) Kidneys were collected from cGVHD mice at week 12 after disease induction and were fixed in formalin. Sections from control Ig- or DTA-1-treated mice were stained with H\&E or PAS. Upper panel, H\&E staining (lower magnification); middle panel, H\&E staining (higher magnification); lower panel, PAS staining. (B) Kidneys from 12-week cGVHD mice were collected and snap-frozen, and sections were stained with FITC-labeled rat anti-mouse IgG. (C) DTA-1 treatment increased survival ( $n=10$ per group). Kidneys of $n=5-10$ per group were analyzed for histology and histochemistry. Data shown are representative of more than 3 independent experiments.

DTA-1-treated cGVHD mice (Figure 2A). Consistent with the histological examination, IgG deposition in the kidney was significantly decreased in the DTA1-treated cGVHD mice (Figure 2B). Finally, we confirmed that DTA-1-treated CGVHD mice had increased survival (Figure 2C). Thus, DTA-1 treatment has an effect on CGVHD mortality as well as morbidity. Taken together, our findings suggest that DTA-1 treatment prevents cGVHD by inhibiting the production of autoantibodies, and so inhibiting the induction and development of renal disease.

To address the mechanism underlying the inhibition of cGVHD by DTA-1 treatment, we investigated the lymphocyte populations in cGVHD mouse spleens. We consistently found a marked decrease in B-cell numbers 7 days after disease induction and B-cell lymphopenia after 14 days (Figure 3). Since B cells involve the production of autoantibody in cGVHD, our results indicate that elimination of $B$ cells may be responsible for the inhibition of 

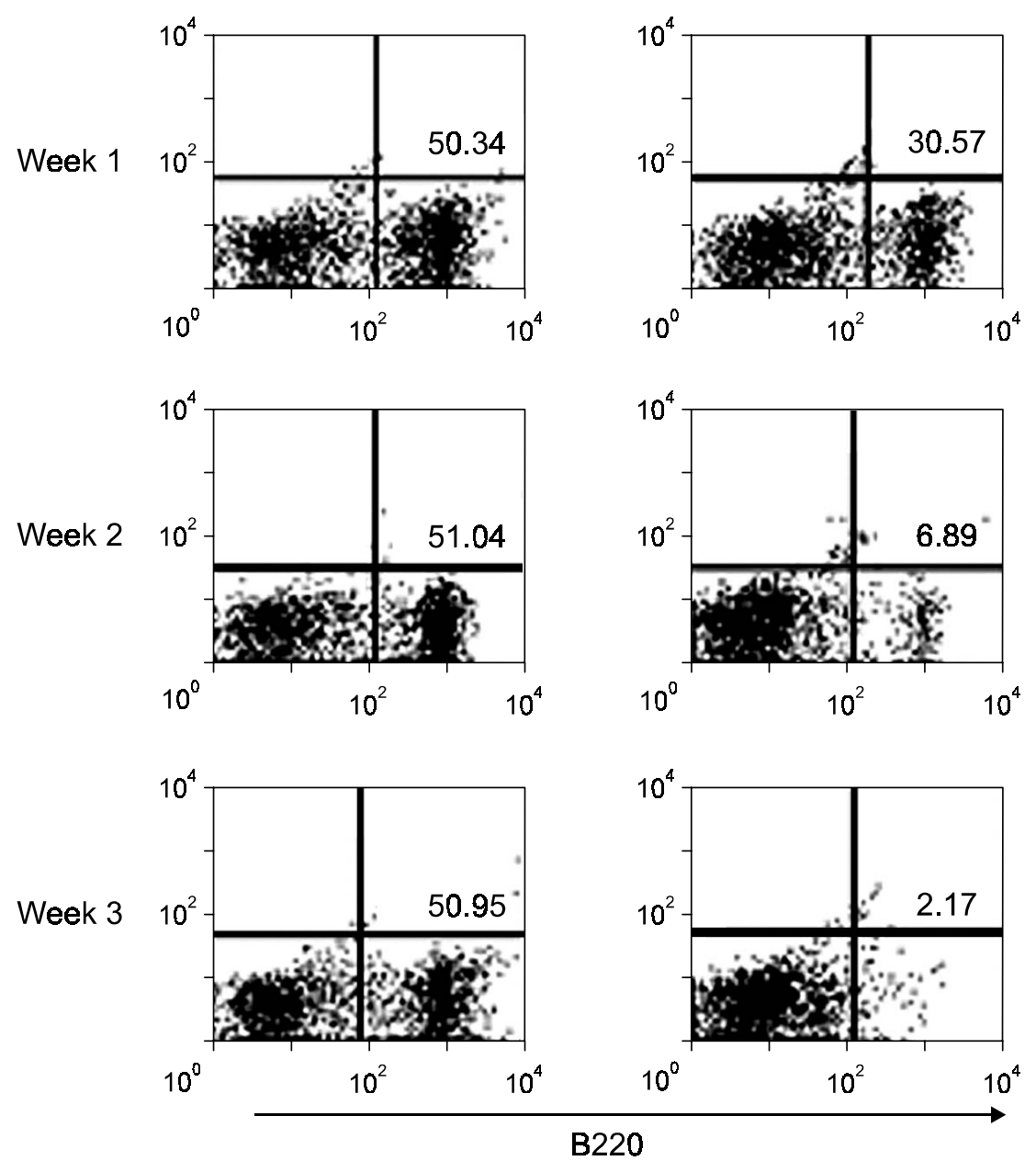

Figure 3. B cells are deleted after GITR stimulation. Splenocytes prepared at weeks 1,2 , and 3 after disease induction were analyzed for B220 staining. FACS plots shown are representative of more than 3 independent experiments $(n=3-5$ per group).

autoantibody production by DTA-1 treatment.

The effect of DTA-1 could not be explained by the breakdown of immunosuppressive activity of $\mathrm{CD} 4^{+} \mathrm{CD} 25^{+}$ regulatory $\mathrm{T}$ cells. To determine whether or not the DTA-1-mediated inhibition of CGVHD is indeed independent of $\mathrm{CD} 4^{+} \mathrm{CD} 25^{+}$regulatory $\mathrm{T}$ cells, we induced $\mathrm{CGVHD}$ by transferring $\mathrm{CD} 4^{+} \mathrm{CD} 25^{+} \mathrm{T}$ celldepleted $\mathrm{DBA} / 2$ parental cells into $\mathrm{BDF}_{1}$ recipients. We previously demonstrated that donor $\mathrm{CD} 4^{+} \mathrm{CD} 25^{+}$ regulatory $\mathrm{T}$ cells were able to inhibit cGVHD (Kim et al., 2005). Our results showed that deletion of $\mathrm{CD} 4^{+} \mathrm{CD} 25^{+}$regulatory $\mathrm{T}$ cells did not influence the effect of DTA-1 on levels of anti-DNA $\lg _{1}$ and survival (Figure 4). These results clearly demonstrate that there exists an anti-GITR antibody's mechanism of action that is independent of $\mathrm{CD} 4^{+} \mathrm{CD} 25^{+}$ regulatory $\mathrm{T}$ cells.

\section{Discussion}

The main finding presented in this report is to reveal a GITR co-stimulatory pathway independent of $\mathrm{CD} 4^{+} \mathrm{CD} 25^{+}$regulatory $\mathrm{T}$ cells in vivo. To be equally important, we provide a possibility of GITR stimulation as an immunotherapeutic tool for cGVHD and presumably other autoimmune diseases. There are reports showing in vitro that GITR signals costimulate $\mathrm{CD} 4^{+} \mathrm{CD} 25^{-}$conventional T cells (Ji et al., 2004; Kanamaru et al., 2004; Kohm et al., 2004; Ronchetti et al., 2004) and CD8 ${ }^{+} \mathrm{T}$ cells (Ronchetti et al., 2004; Muriglan et al., 2004; La et al., 2005). In our cGVHD model, in vivo ligation of GITR prevents donor $\mathrm{CD}^{+} \mathrm{T}$-cell anergy and subsequently induces a sustained activation of alloreactive donor $\mathrm{CD}^{+} \mathrm{T}$ cells (Kim et al., 2006). Since the inhibition of cGVHD by GITR stimulation occurred in the absence of $\mathrm{CD} 4^{+} \mathrm{CD} 25^{+}$regulatory $\mathrm{T}$ cells, our results also indicate that GITR signals directly co-stimulate conventional $\mathrm{T}$ cells in vivo.

There could be several possible explanations for the mechanism underlying our observations. It has been shown that GITR co-stimulation induces the activation-induced cell death (AICD) of alloreactive 

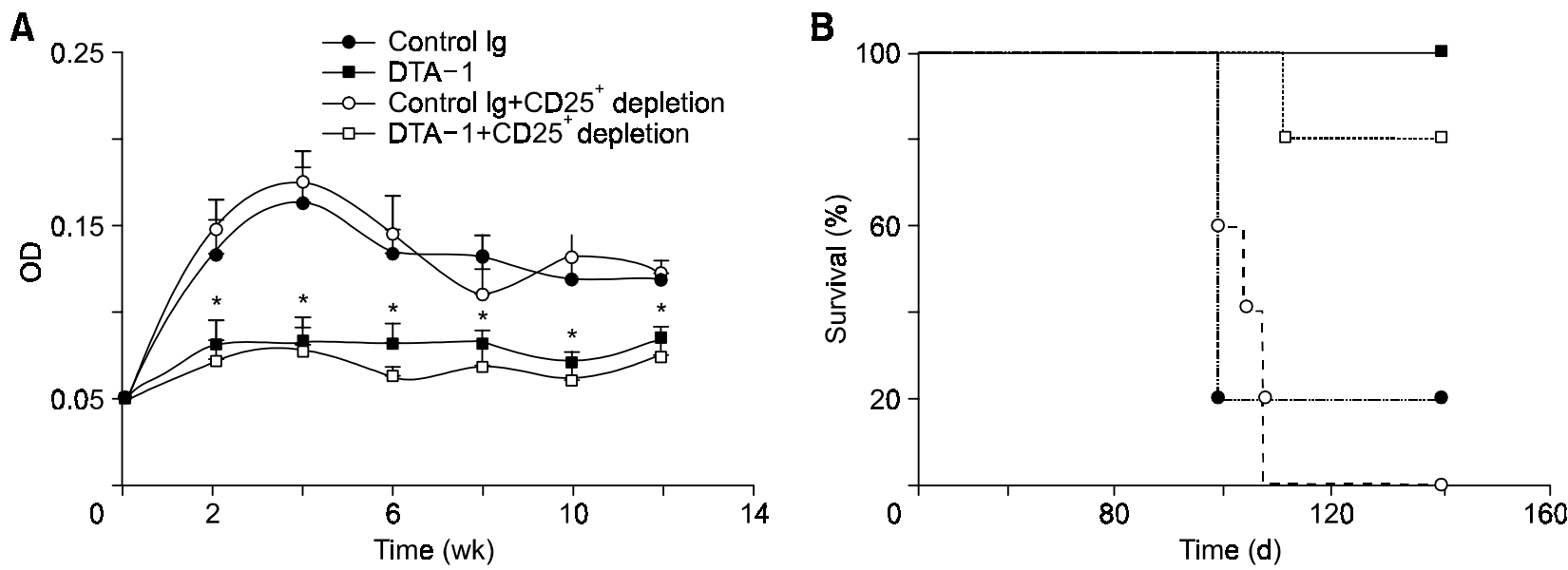

Figure 4. $C D 4^{+} \mathrm{CD} 25^{+}$regulatory T cells are not required for DTA-1-mediated inhibition of cGVHD. Donor $\mathrm{CD} 4^{+} \mathrm{CD} 25^{+}$regulatory T cells were depleted before transfer using anti-CD25-conjugated microbeads. (A) OD values are mean $\pm \mathrm{SD}$ of $n=10$ per group at 10 -fold dilution of samples. ${ }^{*} P<0.05$, between control Ig-treated groups and DTA-1-treated groups. (B) Survival curves ( $n=10$ per group). Data shown are representative of more than 3 independent experiments.

$\mathrm{CD} 4^{+} \mathrm{T}$ cells, whereas it enforces the activity of alloreactive $\mathrm{CD}^{+} \mathrm{T}$ cells (Muriglan et al., 2004). Therefore, one explanation is that GITR stimulation might prevent CGVHD by eliminating donor $\mathrm{CD} 4^{+} \mathrm{T}$ cells required for the development of cGVHD (Morris et al., 1999). Stimulation of 4-1BB, a similar member of the TNF receptor superfamily, has been shown to be highly efficient in inducing the AICD of donor $\mathrm{CD}^{+}{ }^{\mathrm{T}}$ cells ( $\mathrm{Kim}$ et al., 2005), and so completely preventing cGVHD. However, we could not obtain any evidence supporting the hypothesis that GITR stimulation with a lower lose of DTA-1 $(200 \mu \mathrm{g})$ preferentially induces the AICD of donor $\mathrm{CD} 4^{+} \mathrm{T}$ cells (not shown). Another possibility is that GITR stimulation might block cGVHD through enhancing the cytotoxic activity of alloreactive donor $\mathrm{CD}^{+} \mathrm{T}$ cells that can kill host splenocytes, including autoreactive B cells. This explanation is supported by our observations that DTA-1 was capable of eliminating B cells (Figure 3 ). Indeed, our study indicates that treatment of a higher dose of antiGITR antibody can strongly activate alloreactive donor $\mathrm{CD}^{+} \mathrm{T}$ cells in $\mathrm{CGVHD}$ and shift cGVHD towards an acute form (Kim et al., 2006). The activation of donor $\mathrm{CD} 8^{+} \mathrm{T}$ cells subsequently may lead to B-cell killing through two mechanisms: direct killing by their cytotoxic activity and indirect killing via secreting IFN- $\gamma$ (Kim et al., 2006; Sun et al., 2002).

Traditionally, immunotherapy has been targeted for blockade of co-stimulatory pathways to inhibit autoimmune diseases and graft rejection. Paradoxically, recent reports have provided evidence that stimulation of co-stimulatory pathways is highly potent in blocking the progression of autoimmune diseases (Maur et al., 2002; Sun et al., 2002; Foell et al., 2003; Seo et al., 2004) or GVHD (Yu et al., 2004; Kim et al., 2005). The therapeutic effect of strong co-stimulation in vivo is due to the deletion of autoreactive or alloreactive $\mathrm{CD} 4^{+} \mathrm{T}$ cells. Therefore, administration of agonistic monoclonal antibodies against co-stimulatory molecules offers a promising new therapeutic approach for autoimmune diseases and GVHD.

\section{Acknowledgement}

This work was supported by grants from University of Ulsan (2004-0023) and the SRC Fund to the IRC from KOSEF and the Korean Ministry of Science and Technology and by National R\&D Program Grant of the Ministry of Science and Technology (M1047620006-04N1706-00610).

\section{References}

Bergijk EC, Munaut C, Baelds JJ, Prins F, Foidart JM, Hoedemaeker PJ, Brujin JA. A histologic study of the extracellular matrix during the development of glomerulosclerosis in murine chronic graft-versus-host disease. Am J Pathol 1992;140:1147-56

Foell J, Strahotin S, O'Neil SP, McCausland MM, Suwyn C, Haber M, Chander PN, Bapat AS, Yan X-J, Chiorazzi, Hoffmann MK, Mittler RS. CD137 costimulatoy T cell receptor engagement reverses acute disease in lupus-prone NZB $\times$ NZW F 1 mice. J Clin Invest 2003;111:1505-18

Gleichmann E, Pals SY, Rolink AG, Radaszkiewicz T, Gleichmann G. Graft-versus-host-reactions: clues to the etiopathology of a spectrum of immunological diseases. Immunol Today 1984;5:324-32 
Gurney AL, Masters SA, Huang A, Huang RM, Mark M, Baldwin DT, Gray AM, Dowd P, Bush PJ, Helden S, Schow P, Goddard AD, Wood WI, Baker KP, Godowski PJ, Ashkenazi A. Identification of a new member of the tumor necrosis factor family and its receptor, a human ortholog of mouse GITR. Curr Biol 1999;9:215-8

Ji H-b, Liao G, Faubion WA, Abadia-Molina AC, Cozzo C, Laroux FS, Canton A, Terhorst C. Cutting edge: The natural ligand for glucocorticoid-induced TNF-related protein abrogates regulatory T cell suppression. J Immunol 2004;172: 4686-90

Kanamaru F, Youngnak $P$, Hashiguchi M, Nishioka T, Takahashi T, Sakaguch S, Ishikawa I, Azuma M. Costimulation via glucocorticoid-induced TNF receptor in both conventional and $\mathrm{CD} 25^{+}$regulatory $\mathrm{CD} 4^{+} \mathrm{T}$ cells. J Immunol 2004;172:7306-14

Kim J, Choi WS, La S, Suh J-H, Kim B-S, Cho HR, Kwon BS, Kwon B. Stimulation with 4-1BB (CD137) inhibits chronic graft-versus-host disease by inducing activation- induced cell death of donor CD4 ${ }^{+}$T cells. Blood 2005;105: 2206-13

Kim J, Choi WS, Kang H, Kim HJ, Suh JH, Sakaguchi S, Kwon B. Conversion of alloantigen-specific $\mathrm{CD}^{+}$T-cell anergy to $\mathrm{CD}^{+} \mathrm{T}$-cell priming through in vivo ligation of glucocorticoid-induced TNF receptor. J Immunology. In press

Kohm AP, Williams JS, Miller SD. Cutting edge: Ligation of the glucocorticoid-induced TNF receptor enhances autoreactive $\mathrm{CD}^{+} \mathrm{T}$ cell activation and experimental autoimmune encephalomyelitis. J Immunol 2004;172:4686-90

Kwon B, Yu KY, Ni J, Yu GL, Jang IK, Kim YJ, Xing L, Liu D, Wang SX, Kwon BS. Identification of a novel activationinduced protein of the tumor necrosis factor receptor superfamily and its ligand. J Biol Chem 1999;274:6056-61

Kwon B, Kim B-S, Cho HR, Park J-E, Kwon BS. Involvement of tumor necrosis factor receptor superfamily (TNFRSF) members in the pathogenesis of inflammatory diseases. Exp Mol Med 2003;35:8-16

La S, Kim E, Kwon B. In vivo ligation of glucocorticoid-induced TNF receptor enhances the T-cell immunity to herpes simplex virus type 1. Exp Mol Med 2005;37:193-8

Maur C, Mars LT, Londei M. Therapeutic activity of agonistic monoclonal antibodies against CD40 in a chronic autoimmune inflammatory process. Nat Med 2000;6:673-9

McHugh RS, Whitters MJ, Piccirillo CA, Young DA, Shevach EM, Collins M, Byrne MC. CD4 ${ }^{+} \mathrm{CD} 25^{+}$immunoregualtory T cells: gene expression analysis reveals a functional role for the glucocorticoid TNF receptor. Immunity 2002;16:311-23

Morris SC, Cheek RL, Cohen PL, Eisenberg RA. Autoantibodies in chronic graft versus host result from cognate T-B interactions J Exp Med 1990;171:503-17

Muriglan SJ, Ramirez-Montagut T, Alpdogan O, van Huystee TW, Eng JM, Hubbard VM, Kochman AA, Tjoe KH, Riccardi C,
Pandolfi PP, Sakaguchi S, Houghton AN, van den Brink VRM. GITR activation induces an opposite effect on alloreactive $\mathrm{CD}^{+}$and $\mathrm{CD} 8^{+} \mathrm{T}$ cells in graft-versus-host disease. J Exp Med 2004;200:149-57

Murphy WJ, Blazar BR. New strategies for preventing graft-versus-host disease. Curr Opin Immunol 1999;11: 509-15

Murphy WJ. Revisiting graft-versus-host disease models of autoimmunity: new insights in immune regulatory processes. J Clin Invest 2000;106:745-7

Nocentini G, Giunchi L, Rochetti S, Krusz LT, Bartoli A, Moraca R, Migliorati G, Riccardi CA. A new member of the tumor necrosis factor/nerve growth factor receptor family inhibits T cell receptor-induced apoptosis. Proc Nat'l Acad Sci USA 1999;94:6216-21

Rolink AG, Gleichmann H, Gleichmann E. Diseases caused by reactions of $T$ lymphocytes to incompatible structures of the major histocompatibility complex, VII. Immune-complex glomerulonephritis. J Immunol 1983;130:209-15

Ronchetti S, Zollo O, Bruscoli S, Agostini M, Bianchini R, Nocentini G, Ayroldi E, Riccardi C. Frontline: GITR, a member of the TNF receptor superfamily, is costimulatory to mouse T lymphocyte subpopulation. Eur J Immnol 2004; 34:613-22

Seo SK, Choi JH, Kim YH, Kang WJ, Park HY, Huh JH, Choi BK, Vinay DS, Kwon BS. 4-1BB-mediated immunotherapy of rheumatoid arthritis, Nat Med 2004;10:1088-94

Shimizu J, Yamazaki S, Takahashi T, Ishida Y, Sakaguchi S. Stimulation of $\mathrm{CD}^{2} 5^{+} \mathrm{CD} 4^{+}$regulatory T cells through GITR breaks immunological self-tolerance. Nat Immunol 2002;3: 135-42

Sun Y, Chen HC, Subudhi SK, Chen J, Koka R, Chen L, Fu Y. Costimulatory molecule-targeted antibody therapy of a spontaneous autoimmune disease. Nat Med 2002;8:1405-13

Van Rappard-Van Der Veen FM, Radaszkiewicz T, Terraneo L, Gleichmann E. Attempts at standardization of lupus-like graft-vs-host disease: inadvertent repopulation by $\mathrm{DBA} / 2$ spleen cells of $\mathrm{H}-2$ different nonirradiated $\mathrm{F}_{1}$ mice. J Immunol 1983;130:2693-701

Via CS, Shearer GM. T-cell interactions in autoimmunity: Insights from a murine model of graft-versus-host disease. Immunol Today 1988;9:207-13

Wood KJ, Sakaguchi S. Regulatory T cells in transplantation tolerance. Nat Rev Immunol 2003;3:199-220

Yu XZ, Albert MH, Martin PJ, Anasetti C. CD28 ligation induces transplantation tolerance by IFN- $\gamma$-dependent depletion of $\mathrm{T}$ cells that recognized alloantigens. J Clin Invest 2004;113:1624-30 